\title{
Two new species of Hypostomus Lacépède (Teleostei: Loricariidae) from the upper rio Paraná basin, Central Brazil
}

\author{
Cláudio H. Zawadzki ${ }^{1}$, Claude Weber ${ }^{2}$ and Carla S. Pavanelli ${ }^{1}$
}

Two new species of Hypostomus Lacépède (Teleostei: Loricariidae) from the rio Paranaíba and rio Grande basins, both in the upper rio Paraná basin, central Brazil, are described herein. One of them is distinguished from all congeners, except $H$. albopunctatus, by having the pectoral-fin spine length equal to or smaller than the pelvic-fin spine. From H. albopunctatus, it is distinguished by having round dark spots (vs. pale) on body and fins. The second species is distinguished from all congeners, except $H$. multidens and $H$. ternetzi, by having more than 115 teeth (vs. less than 109) per ramus on dentary and premaxilla. It is distinguished most readily from H. ternetzi by having teeth with two symmetrical ( $v$ s. asymmetrical) cusps. It is distinguished from H. multidens by having round dark spots (vs. pale) over body and fins.

Duas novas espécies de Hypostomus Lacépède (Teleostei: Loricariidae) das bacias dos rios Grande e Paranaíba, ambos da bacia do alto rio Paraná, Brasil Central, são descritas aqui. Uma delas é diferenciada de todas as congêneres, exceto $H$. albopunctatus, por possuir o espinho da nadadeira peitoral de comprimento igual ou menor que o espinho da nadadeira pélvica. De H. albopunctatus, é diferenciada por ter por ter pintas arredondadas escuras (vs. claras) sobre o corpo e nadadeiras. A segunda espécie é distinguida de todas as congêneres, exceto $H$. multidens e H. ternetzi, por ter mais de 115 ( $v s$. menos de 109) dentes em cada hemisérie no dentário e pré-maxilar. Esta é prontamente distinguida de $H$. ternetzi por ter dentes com duas cúspides simétricas ( $v s$. cúspides assimétricas). Esta é distinguida de H. multidens por ter pintas escuras arredondadas sobre o corpo e nadadeiras ( $v s$. pintas claras).

Key words: Catfishes, Neotropical fishes, Siluriformes, Taxonomy.

\section{Introduction}

Hypostomus occurs widely throughout the neotropics and is one of the most speciose genera among siluriforms, comprising about 117 to 130 species. The lower count is according to Ferraris (2007) who recognized Aphanotorulus, Isorineloricaria and Squaliforma as valid genera. The higher count is according to Armbruster (2004) and Armbruster et al. (2007) who synonymized these taxa with Hypostomus.

The upper rio Paraná basin is known as region of endemism for fishes (Britski \& Langeani, 1988; Vari, 1988) compared to the remaining portions of the La Plata basin, which also includes rio Iguaçu, lower rio Paraná, rio Paraguay, and rio Uruguay basins. The upper rio Paraná basin has been reported to have 21 species of Hypostomus (Weber, 2003; Jerep et al., 2007). Representatives of the genus are found in almost all aquatic habitats, from large main rivers to small rivulets. Ichthyological surveys by the Núcleo de Pesquisas em Limnologia, Ictiologia e Aqüicultura (Nupélia), of the Universidade Estadual de Maringá, jointly with Furnas Centrais Elétricas, provided five years of monthly ichthyological samples from the rio Corumbá basin, a tributary to rio Paranaíba, in Goiás State, central Brazil. These surveys provided enough material to distinguish two new species of $\mathrm{Hy}$ postomus. Both are diagnosed from congeners by color, morphometric and meristic traits, and are described herein.

\section{Material and Methods}

All examined specimens were collected during five years of monthly sampling carried out by Nupélia. Institutional abbreviations follow standard ASIH codons listed at http:// www.asih.org/files/codons.pdf, with the addition of NUP for Coleção Ictiológica do Nupélia. Measurements and counts

\footnotetext{
${ }^{1}$ Universidade Estadual de Maringá, Núcleo de Pesquisas em Limnologia, Ictiologia e Aqüicultura (Nupélia), Av. Colombo, 5790, 87020-900 Maringá, PR, Brazil. chzawadzki@hotmail.com, carlasp@nupelia.uem.br. Send reprint requests to CHZ.

${ }^{2}$ Département d'Herpétologie et d'Ichtyologie, Muséum d'Histoire Naturelle, Case postale 6434, CH-1211 Genève 6, Switzerland. claude.weber@ville-ge.ch
} 
were taken from the left side of the body whenever possible. Body plate nomenclature follows Schaefer (1997), except plates in dorsal series anterior to dorsal spine are referred to as predorsal plates following Oyakawa et al. (2005). Measurements follow Boeseman (1968) modified by Weber (1985), with addition of lower lip width (measured at insertion of maxillary barbels); and lower lip length (taken at midline, from just posterior of dentary rami to distal border of lip). All measurements were taken point to point with digital calipers to the nearest $0.1 \mathrm{~mm}$. Abbreviations used are: HL (head length), SL (standard length), and TL (total length).

\section{Hypostomus denticulatus, new species}

Fig. 1

Hypostomus sp. 7.- Zawadzki, 2001: 21 [photo; rio Corumbá, affluent of rio Paranaíba; comparison to other species of Hypostomus; allozymes].- Pavanelli et al., 2007: 61 [rio Corumbá basin, affluent of rio Paranaíba].

Holotype. MZUSP 98770, 161.9 mm SL, Brazil, Goiás state, Município de Caldas Novas, rio do Peixe, tributary to rio Corumbá, rio Paranaíba drainage, Pires do Rio, 17³4'24”'S, 48²9'50”W, 21 Sep 1996, Nupélia.

Paratypes. All from Brazil, Goiás State, upper rio Paraná basin: ANSP 187499, 1, $165.7 \mathrm{~mm} \mathrm{SL}$, rio do Peixe, tributary to rio Corumbá, Município de Caldas Novas, Pires do Rio, 17³6’06”S, 48²8'01'W, 8 Oct 1999, Nupélia; MHNG 2709.052, 1, 172.9 mm SL, rio Pirapitinga, tributary to rio Corumbá, Município de Caldas Novas, Pires do Rio, 1743’37’'S, 48³2'54”'W, 6 Nov 1999, Nupélia; NUP 480, 3, 107.3-147.1 mm SL, rio Corumbá (Corumbá Reservoir), tributary to rio Paranaíba, Município de Caldas Novas, Ipameri, 1742’43”S, 48²9'52”W, 12 Nov 1996 to 11 May 1999, Nupélia; NUP 4233, 1, $165.8 \mathrm{~mm}$ SL, rio do Peixe, tributary to rio Corumbá, Município de Caldas Novas, Pires do Rio, 17³4'24'S, 48²9'50”W, 5 Oct 1999, Nupélia; NUP 4306, 2, 144.3-158.5 mm SL, rio Corumbá, tributary to rio Paranaíba, Município de Pires do Rio, Ipameri, 17²9'02'S, 48²2'13”W, 22 May 1996, Nupélia; NUP 4308, 2, 166.7-186.4 mm SL, rio Corumbá (downstream the Corumbá Reservoir), tributary to rio Paranaíba, Município de Caldas Novas, Corumbaíba, 1800'33”'S, 48³2'19”W, 7 Feb 1999, Nupélia; NUP 5574, 2, 117.7-136.9 mm SL, rio Corumbá (Corumbá Reservoir), tributary to rio Paranaíba, Município de Caldas Novas, Corumbaíba, 1743'37'S, 48³2'54’'W, 10 Nov 1996, Nupélia; NUP 5617, 2, 93.1-99.8 mm SL, rio do Peixe, tributary to rio Corumbá, Município de Pires do Rio, Ipameri, 17³6'S, 48²4'"W, 28 Oct 1997, Nupélia; NUP 5619, 1, 134.5 mm SL, Corumbá Reservoir, rio Corumbá, tributary to rio Paranaíba, Município de Caldas Novas, Corumbaíba, 1743'37’'S, 48³2'54'W, 15 Dec 1996, Nupélia; NUP 5620, 2, 182.6-191.3 mm SL, rio Corumbá (Corumbá Reservoir), tributary to rio Paranaíba, Município de Caldas Novas, Ipameri, 1742'43”S, 48²9'52”'W, Aug 1997, Nupélia; NUP 5635, 1, $156.6 \mathrm{~mm}$ SL, rio do Peixe, tributary to rio Corumbá, Município de Pires do Rio, Ipameri, 17³6'06”S, 48²8'01'W, 20 May 1996, Nupélia; NUP 5637, 1, $120.1 \mathrm{~mm}$ SL, rio Corumbá, tributary to rio Paranaíba, Município de Pires do Rio, Ipameri, 17²9’02”S, 48²2'13"W, 6 Dec 1998, Nupélia. Non-measured paratypes: Goiás State: NUP 479, 6, 107.9-132.4 mm SL, rio do Peixe, tributary to rio Corumbá, Município de Pires do Rio, Ipameri, $17^{\circ} 36^{\prime} \mathrm{S}$, 48²4'W, 12 Nov 1996, Nupélia; NUP 5571, 5, 90.0-133.2 mm SL, rio do Peixe, tributary to rio Corumbá, Município de Pires do Rio, Ipameri, $17^{\circ} 36^{\prime}$ S, 48²4’W, 10 Nov 1996, Nupélia; NUP 5572, 1, $90.1 \mathrm{~mm}$ SL, rio do Peixe, tributary to rio Corumbá, Município de Pires do Rio, Ipameri, $17^{\circ} 36^{\prime}$ S, 48²4'W, 17 Oct 1996, Nupélia; NUP 5573, 1, $111.7 \mathrm{~mm}$ SL, rio do Peixe, tributary to rio Corumbá, Município de Pires do Rio, Ipameri, $17^{\circ} 36^{\prime}$ S, $48^{\circ} 24^{\prime} \mathrm{W}, 30$ Jun 2001, Nupélia; NUP 5621, 1, 109.1 mm SL, rio Corumbá (Corumbá Reservoir), tributary to rio Paranaíba, Município de Caldas Novas, Ipameri, 1743'37’'S, 48³2'54'W, 21 Oct 1996, Nupélia; NUP 5622, 2, 65.0-145.9 mm SL, rio Corumbá (Corumbá Reservoir), tributary to rio Paranaíba, Município de Caldas Novas, Ipameri, 1743’37’S, 48³2'54”W, 11 Dec 1996, Nupélia. Minas Gerais State: MZUSP 36788, 2, 136.3-154.4 mm SL, rio Paranaíba (São Simão Reservoir), tributary to upper rio Paraná, Município de Cachoeira Dourada, Oct 1985, A.C. Beaumord. Indefinite State: MNRJ 17624, 1, $147.0 \mathrm{~mm} \mathrm{SL}$, rio Preto, corredeira, right margin of rio Paranaíba, city and State not specified on label, 3 Aug 1997, O. Sagim Jr.

Diagnosis. Hypostomus denticulatus is distinguished from all congeners, except $H$. multidens and $H$. ternetzi, by having more than 115 teeth ( $v s$. less than 109) per ramus on dentary and premaxilla. Hypostomus denticulatus is distinguished from similar-looking $H$. ternetzi by having $116-214$ teeth per jaw ramus (mean 167, $\mathrm{n}=20$ ) vs. 39-127 teeth per ramus (mean $81.4, \mathrm{n}=20)$; beige to light-brown body color $v s$. dark brown; larger orbital diameter, 18.5 to $21.2 \%$ of $\mathrm{HL}(\mathrm{n}=20)$ vs. 14.5 to $16.1 \%(\mathrm{n}=20)$; abdomen naked $v s$. abdomen partially plated; and teeth with two symmetrical cusps (Fig. 2a) vs. two asymmetrical cusps (Fig. 2b). Hypostomus denticulatus is distinguished from $H$. multidens by having dark ( $v s$. pale) spots over body and fins (Fig. 3).

Description. Counts and measurements in Table 1. Body relatively short with rough plates. Cleithral width greater than head depth. Dorsal profile rising somewhat irregularly at an angle slightly less than $45^{\circ}$ from snout tip to dorsal-fin origin, and decreasing gently from that point to end of caudal peduncle. Head broad and moderately depressed, covered dorsally with dermal ossifications, except for small amorphous naked area on snout tip. Anterior profile of snout rounded in dorsal view. Median longitudinal bulge associated with mesethmoid usually conspicuous from snout tip to transverse line between nares. Eye large (18.5 to $21.2 \%$ of HL), dorsolaterally placed. Interorbital space moderately concave in frontal view. A pair of weak ridges on dorsal surface of head, each beginning lateral to naris, passing through upper margin of orbit and terminating on posterior portion of pteroticsupracleithrum. Supraoccipital with weak median ridge and slight, broadly triangular posterior process bordered by single predorsal plate, partially divided in some specimens. Predorsal region with weak medial keel; its uppermost portion flat.

Lips well developed and transversely ellipsoidal. Lower lip reaching or almost reaching transverse line between gill openings, its inner surface covered with numerous small papillae. Maxillary barbel short with free tip. Mouth large. Teeth long, very slender, bicuspid, and curved inward distally; mesial cusp similar in length and form to lateral cusp (Fig. 2a). 


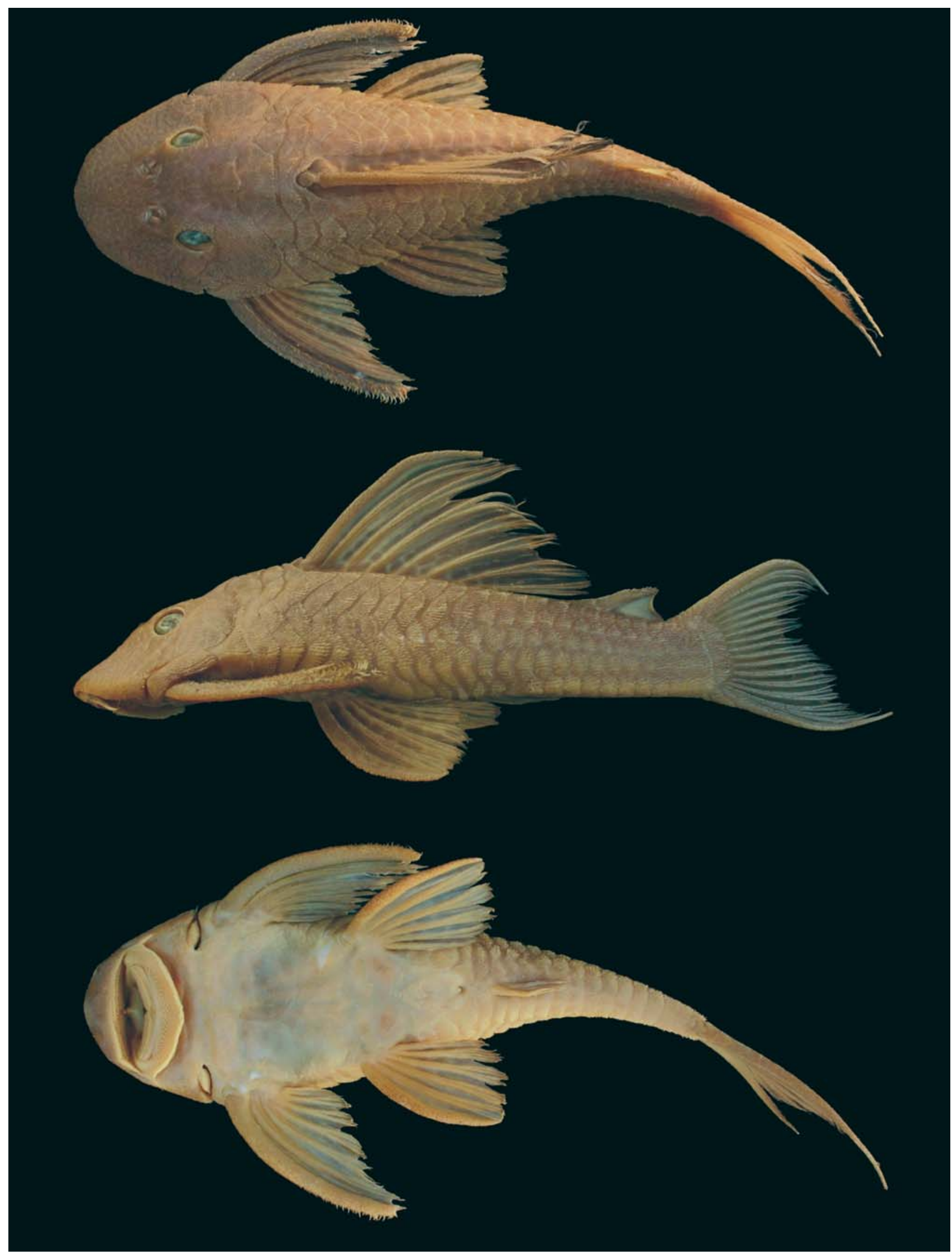

Fig. 1. Hypostomus denticulatus, holotype, Brazil, Goiás state, Município de Caldas Novas, rio do Peixe, tributary to rio Corumbá, MZUSP 98770, 161.9 mm SL. Dorsal, lateral, and ventral views. 
a

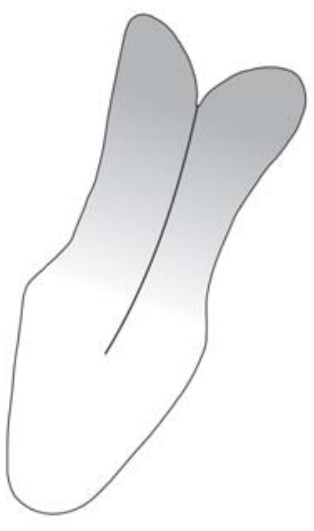

\section{b}

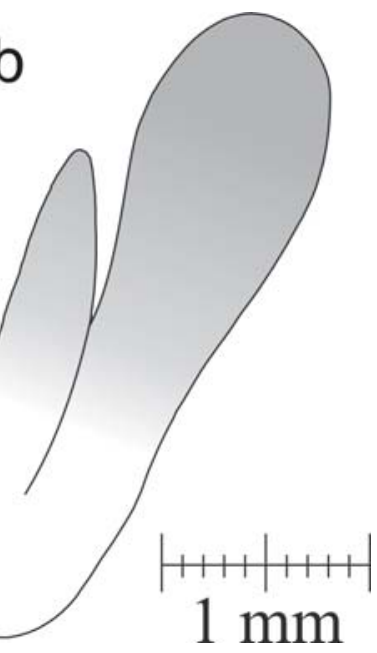

Fig. 2. Bicuspid premaxillary teeth of a, Hypostomus denticulatus with symmetrical cusps, and $\mathbf{b}, H$. ternetz $i$ with asymmetrical cusps. Ventral view.

Dentary teeth usually not overlapping medially. Dentary ramus flat, straight, and approximately forming a straight angle (usually ranging from $160^{\circ}$ to $180^{\circ}$ ).

Five rows of slightly spinulose plates on side of body. Dorsal series of plates starting at vertical through dorsal-fin origin. A weak longitudinal keel begins on first plate of dorsal series and continues until dorsal procurrent caudal-fin plates. Mid-dorsal series of plates without keel or with a very weak keel. Median series bearing lateral line. Mid-ventral series forming longitudinal ridge along first five or six plates. Plates in ventral series right-angled transversely on caudal peduncle, forming a strong keel along lower portion of peduncle. Caudal peduncle roughly triangular in cross section.

Upper and lower lips without scutelets. Ventral surfaces of head and abdomen completely naked in specimens up to $131.2 \mathrm{~mm} \mathrm{SL}$; larger specimens with small platelets distributed just anterior to gill opening, in narrow transverse band between gill openings, laterally on abdomen between pectoral and pelvic fins (contacting ventral plates), and anterior to urogenital opening. Preanal plate partially exposed in specimens up to $129.8 \mathrm{~mm} \mathrm{SL}$, usually completely covered with skin in larger specimens.

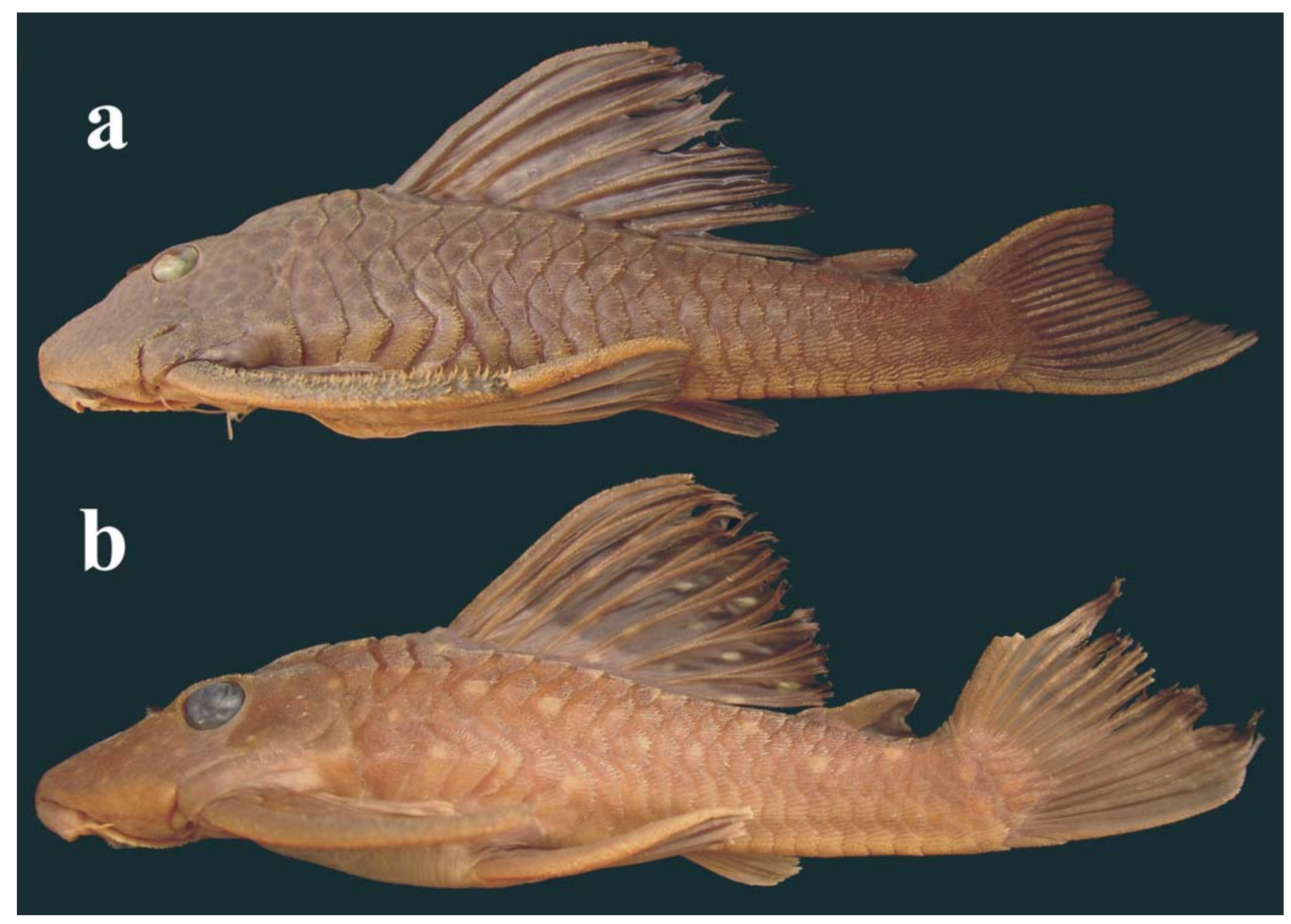

Fig. 3. a, Hypostomus denticulatus, paratype, NUP 4308, $194.3 \mathrm{~mm} \mathrm{SL}$, and b, H. multidens, NUP 5340, $157.0 \mathrm{~mm}$ SL. 
Dorsal-fin origin situated two lateral-plate rows anterior to vertical through pelvic-fin origin. Dorsal fin large with flexible spine and seven branched rays; two posteriormost rays reaching or almost reaching adipose-fin origin. Adipose-fin spine straight and well developed. Pectoral fin with moderately inward-curved spine and six branched rays; distal margin straight. Pectoral-fin spine covered with poorly-developed odontodes; odontodes more developed distally in some larger specimens. Pectoral fin inserted on same horizontal plane as pelvic fin such that pectoral spine, when adpressed, lies on top of and reaches to approximately middle of pelvicfin spine. Pelvic fin with flexible and slightly inward-curved spine and five branched rays; distal border straight. Pelvicfin spine flattened ventrally; when adpressed spine tip reaches to about middle of anal-fin spine. Anal fin with flexible spine and four branched rays; spine tip reaching fifth plate posterior to its origin. Caudal fin slightly emarginate, with two longer outer spines and 14 inner branched rays; ventral lobe longer than dorsal lobe.
Color in alcohol. Background color of dorsal and lateral surfaces of head and body beige to light-brown. Head, dorsum, flanks and fins covered by many large dark spots. Dark spots generally merge into short and narrow vermiculations on anterior portion of head, becoming isolated and roundish on pterotic-supracleithrum and more elongate posteriorly. Spots most conspicuous on head and usually fade gradually on trunk towards caudal peduncle. Background color of ventral surfaces of head and body lighter than dorsal portions, except ventral portion of snout uniformly dark brown. Upper and lower lips and ventral surface of head without spots. Abdomen usually without spots or with very faded irregularly spaced dark spots in a few specimens. Ventral surface of caudal peduncle without spots.

Dorsal fin with roundish dark spots only on its base; spots merging distally into bands on interradial membranes paralleling rays. Adipose fin and caudal fin brown. Pectoral fin and pelvic fin with dark spots on spine, rays and interradial membranes. Anal fin with diffuse dark markings.

Table 1. Morphometric data and counts for Hypostomus denticulatus and H. heraldoi from the upper rio Paraná basin, Brazil. Means are presented for measurements, and modes for counts. SD = standard deviation.

\begin{tabular}{|c|c|c|c|c|c|c|}
\hline & \multicolumn{3}{|c|}{ H. denticulatus $(\mathrm{n}=20)$} & \multicolumn{3}{|c|}{ H. heraldoi $(\mathrm{n}=20)$} \\
\hline & Holotype & Range & Mean/SD & Holotype & Range & Mean/SD \\
\hline Standard length & \multicolumn{5}{|c|}{ Percents of SL } & 167.2 \\
\hline Predorsal length & 39.5 & $37.6-43.0$ & $40.5 \pm 1.43$ & 41.6 & $40.5-44.9$ & $42.8 \pm 1.16$ \\
\hline Head length & 32.3 & $30.4-35.2$ & $33.0 \pm 1.40$ & 32.7 & $32.7-36.9$ & $34.6 \pm 1.07$ \\
\hline Cleithral width & 33.9 & $32.1-35.6$ & $33.6 \pm 0.90$ & 30.8 & $29.7-33.9$ & $31.8 \pm 1.05$ \\
\hline Head depth & 18.5 & $18.2-20.4$ & $19.1 \pm 0.66$ & 16.5 & $16.5-18.2$ & $17.4 \pm 0.48$ \\
\hline Inter-dorsal length & 15.2 & $13.9-15.2$ & $14.7 \pm 0.41$ & 18.6 & $17.2-20.4$ & $18.8 \pm 0.98$ \\
\hline Caudal-peduncle length & 33.6 & $30.6-35.8$ & $33.5 \pm 1.42$ & 29.2 & $27.0-31.8$ & $29.1 \pm 1.09$ \\
\hline Caudal-peduncle depth & 11.1 & $10.3-11.2$ & $10.9 \pm 0.25$ & 10.3 & $10.3-11.3$ & $10.8 \pm 0.30$ \\
\hline Dorsal-spine length & 35.8 & $30.3-37.2$ & $33.6 \pm 2.09$ & 22.1 & $22.0-26.6$ & $23.3 \pm 1.10$ \\
\hline Thoracic length & 21.5 & $21.5-24.7$ & $23.2 \pm 1.06$ & 21.5 & $21.2-25.3$ & $23.2 \pm 1.50$ \\
\hline \multicolumn{7}{|c|}{ Percents of head length } \\
\hline Cleithral width & 104.9 & $94.5-110.1$ & $102.1 \pm 3.76$ & 94.0 & $88.6-94.2$ & $92.0 \pm 1.78$ \\
\hline Head depth & 57.3 & $53.4-64.8$ & $57.9 \pm 3.26$ & 50.3 & $48.0-52.9$ & $50.2 \pm 1.34$ \\
\hline Snout length & 65.8 & $62.5-66.5$ & $64.7 \pm 1.22$ & 69.9 & $68.4-72.2$ & $70.0 \pm 0.94$ \\
\hline Orbital diameter & 18.8 & $18.5-21.2$ & $20.1 \pm 0.90$ & 12.2 & $12.0-13.7$ & $13.0 \pm 0.55$ \\
\hline Interorbital width & 36.6 & $31.3-38.3$ & $33.9 \pm 2.04$ & 31.9 & $30.1-37.1$ & $33.3 \pm 1.65$ \\
\hline Mandibular width & 24.8 & $24.8-27.8$ & $26.5 \pm 0.83$ & 20.3 & $19.9-22.1$ & $20.8 \pm 0.64$ \\
\hline \multicolumn{7}{|c|}{ Other percents } \\
\hline Snout length/orbital diameter & 28.7 & $28.6-33.9$ & $31.0 \pm 1.76$ & 17.5 & $16.9-19.8$ & $18.5 \pm 0.94$ \\
\hline Interorbital length/orbital diameter & 51.5 & $48.3-66.9$ & $59.6 \pm 5.47$ & 38.4 & $36.1-43.0$ & $38.9 \pm 2.30$ \\
\hline Interorbital length/mandibular width & 67.7 & $67.7-84.6$ & $78.5 \pm 4.93$ & 63.7 & $55.0-68.7$ & $62.4 \pm 4.10$ \\
\hline Predorsal length/first dorsal-fin length & 90.5 & $71.5-98.0$ & $83.1 \pm 7.23$ & 53.3 & $51.0-61.6$ & $54.3 \pm 2.90$ \\
\hline Predorsal length/first pectoral-fin length & 87.1 & $71.3-95.6$ & $83.2 \pm 5.37$ & 60.6 & $55.3-68.4$ & $61.1 \pm 3.21$ \\
\hline Predorsal length/lower caudal-fin length & 102.1 & $77.2-113.0$ & $94.0 \pm 8.84$ & 64.5 & $62.8-83.8$ & $69.6 \pm 5.60$ \\
\hline Caudal-peduncle depth/adipose-fin length & 88.4 & $80.6-93.5$ & $88.4 \pm 3.09$ & 68.0 & $65.2-83.9$ & $76.2 \pm 4.81$ \\
\hline Caudal-peduncle length/caudal-peduncle depth & 33.1 & $29.9-36.0$ & $32.5 \pm 1.47$ & 35.4 & $33.4-39.6$ & $37.2 \pm 1.59$ \\
\hline Cleithral width/mandibulary width & 23.6 & $23.6-27.6$ & $26.0 \pm 0.95$ & 21.6 & $21.3-24.0$ & $22.6 \pm 0.76$ \\
\hline Dorsal-fin base length/inter-dorsal length & 51.3 & $47.8-57.1$ & $51.7 \pm 2.92$ & 86.7 & $73.2-93.5$ & $84.1 \pm 5.01$ \\
\hline Lower lip length/lower lip width & 24.0 & $20.0-28.4$ & $23.4 \pm 2.20$ & 29.2 & $23.0-29.2$ & $27.0 \pm 1.85$ \\
\hline Counts & \multicolumn{5}{|c|}{ Mode } & Mode \\
\hline Median plates series & 26 & $25-26$ & 26 & 26 & $26-27$ & 26 \\
\hline Predorsal plates & 3 & $3-3$ & 3 & 3 & $3-4$ & 3 \\
\hline Dorsal plates below dorsal-fin base & 8 & $8-9$ & 8 & 1 & $7-8$ & 7 \\
\hline Plates between dorsal and adipose fin & 5 & $5-5$ & 5 & 7 & $6-8$ & 7 \\
\hline Plates between adipose and caudal fin & 5 & $4-6$ & 5 & 4 & $4-7$ & 6 \\
\hline $\begin{array}{l}\text { Ventral plates between end of anal-fin base } \\
\text { and caudal fin }\end{array}$ & 15 & $14-15$ & 15 & 12 & $12-16$ & 14 \\
\hline Premaxillary teeth & 162 & $120-214$ & - & 60 & $39-60$ & 54 \\
\hline Dentary teeth & 146 & $116-213$ & 164 & 59 & $38-63$ & 54 \\
\hline
\end{tabular}


Distribution and habitat. Hypostomus denticulatus is known from the rio Corumbá in the vicinity of the Corumbá Reservoir, upper rio Paraná basin, Brazil (Fig. 4). This species was mostly collected in the reservoir of the rio Corumbá just upstream from the dam, and its tributary the rio Areia. Water was turbid, substrates rocky with sand, and riparian vegetation variable and remnant. This species was not found associated with woody debris, and occurs syntopically with $H$. ancistroides, H. iheringii, H. margaritifer, H. regani, Hypostomus sp., and the second new species described herein.

Etymology. From the Latin denticulus, meaning small teeth, plus -atus, meaning provided with.

\section{Hypostomus heraldoi, new species}

Fig. 5

Hypostomus sp. 1.- Zawadzki, 2001: 61 [photo; rio Corumbá, affluent of rio Paranaíba; comparison to other species of Hypostomus; allozymes].- Pavanelli et al., 2007: 61 [rio Corumbá basin, affluent of rio Paranaíba].

Holotype. MZUSP 98771, 217.9 mm SL, Brazil, Goiás State, Município de Caldas Novas, rio Pirapitinga, tributary to rio Corumbá, rio Paranaíba drainage, 1743'37'S, 48³2'54'W, 10 Dec 1999, Nupélia.

Paratypes. All from Brazil, upper rio Paraná basin: Goiás State: ANSP 187500, 1, 152.6 mm SL, rio Corumbá (Corumbá Reservoir), tributary to rio Paranaíba, Município de Caldas Novas, Corumbaíba, 1758'25”S, 48³1'04”W, 17 Oct 1996, Nupélia; MHNG 2709.051, 1, 140.9 mm SL, rio Corumbá (Corumbá Reservoir), tributary to rio Paranaíba basin, Município de Caldas Novas, Corumbaíba, 1750'51'"S, 48³1'54”'W, 11 Nov 1996, Nupélia; NUP 2280, 3, 178.4-194.6 mm SL, rio Pirapitinga, tributary to rio Corumbá, Município de Caldas Novas, Pires do Rio, 1743'37’'S, 48³2'54”'W, 9 Abr 1999, Nupélia; NUP 2281, 1, 200.8 mm SL, rio Corumbá (Corumbá Reservoir), tributary to rio Paranaíba, Município de Caldas Novas, Ipameri, 1743’37’S, 48³2'54”W, 9 Apr 1999, Nupélia; NUP 4042, 1, 141.8 mm SL, rio do Peixe, tributary to rio Corumbá, Município de Caldas Novas, Pires do Rio, 17³4'24’'S, 48²9'50”W, 20 May 1996, Nupélia; NUP 4048, 2, 157.2-189.3 mm SL, rio Pirapitinga, tributary to rio Corumbá, Município de Caldas Novas, Pires do Rio, 1743'37'S, 48³2'54”W, 9 Dec 1999, Nupélia; NUP 4051, 1, 138.3 mm SL, rio Corumbá (Corumbá Reservoir), tributary to rio Paranaíba, Município de Caldas Novas, Ipameri, 1742’43”S, 48²9’52”W, 25 Dec 1997, Nupélia; NUP 5623, 5, 138.2-183.1 mm SL (3, 174.1-176.6 mm SL), rio Pirapitinga, tributary to rio Corumbá, rio Paranaíba drainage, upper rio Paraná basin, Município de Caldas Novas, 1743'37”S, 48³2'54'W, 12 Jan 2000, Nupélia; NUP 5624, 5, 133.2-207.6 mm SL, rio Pirapitinga, tributary to rio Corumbá, Município de Caldas Novas, Pires do Rio, 1743'37'’S, 48³2'54'W, 25 Jan 1998, Nupélia; NUP 5625, 4, 138.4-163.6 mm SL (1, $160.1 \mathrm{~mm} \mathrm{SL),} \mathrm{rio} \mathrm{Pirapitinga,}$ tributary to rio Corumbá, Município de Caldas Novas, Pires do Rio, 1743’37’S, 48³2'54'W, 24 Oct 1997, Nupélia. Non-measured paratypes: Goiás State: NUP 2282, 6, 70.6-192.8 mm SL, rio Corumbá, tributary to rio Paranaíba, Município de Caldas Novas, Pires do Rio, 1743'37'’S, 48³2'54'W, 9 Apr 1999, Nupélia; NUP 5648, 3, 162.4-189.4 mm SL, rio Corumbá, tributary to rio

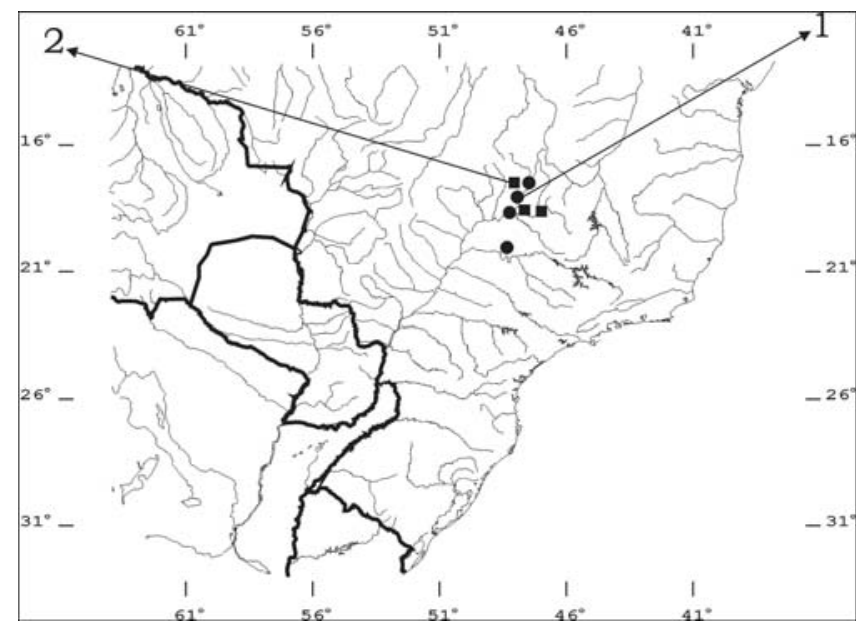

Fig. 4. Map of southeastern South America showing geographic distribution and type-locality (numbers) of Hypostomus heraldoi (dots; $1=$ rio Pirapitinga), and $H$. denticulatus (squares; 2 = rio do Peixe).

Paranaíba, Município de Caldas Novas, Pires do Rio, 1743'37'S, 48³2'54”W, 20 Sep 1996, Nupélia; NUP 5650, 1, 146.4 mm SL, rio Corumbá, tributary to rio Paranaíba, Município de Caldas Novas, Pires do Rio, 1743’37’S, 48³2'54”W, 21 Jun 1997, Nupélia; NUP 5651, 1, $112.3 \mathrm{~mm}$ SL, rio Corumbá, tributary to rio Paranaíba, Município de Caldas Novas, Pires do Rio, 1743’37’S, 48³2'54”W, 11 Nov 1996. NUP 6049, 5, 36.5-104.0 mm SL, córrego Gameleira, tributary to rio Corumbá, Município de Corumbaíba, 1759’05”S, 48²9'46”'W, 17 Jul 2008, C.H. Zawadzki, B.F. Morales \& V.S. Ferreira; NUP 6050, 1, $75.0 \mathrm{~mm} \mathrm{SL}$, córrego Libório, tributary to rio Corumbá, Município de Corumbaíba, $17^{\circ} 55^{\prime} 48^{\prime}$ 'S, 48²8' $57^{\prime}$ 'W, 17 Jul 2008, C.H. Zawadzki, B.F. Morales \& V.S. Ferreira. Minas Gerais State: MZUSP 73222, 2, 79.0-84.0 mm SL, rio Piedade (Fazenda Piedade), tributary to rio Grande, Município de Centralina, $18^{\circ} 38^{\prime} 11$ 'S, 4905'28”W, 2 Aug 2001, P. Gerhard \& F.C.T. Lima; MZUSP 73229, 2, 226.1-236.1 mm SL, rio Piedade (Fazenda Piedade), tributary to rio Grande, Município de Centralina, $18^{\circ} 38^{\prime} 11^{\prime \prime S}, 49^{\circ} 05^{\prime} 28^{\prime \prime} \mathrm{W}, 3$ Aug 2001, P. Gerhard \& F.C.T. Lima; NUP 5696, 1, $115.5 \mathrm{~mm} \mathrm{SL}$, rio Muzambinho, tributary to rio Grande, Município de Poços de Caldas, 21 44'50'S, 46²8'07'W, 24 Nov 2007, L.H.G. Pereira; NUP 5697, 1, 198.8 mm SL, rio Grande (Funil Reservoir), tributary to upper rio Paraná, Município de Perdões, $21^{\circ} 08^{\prime}$ S, $45^{\circ} 01^{\prime} \mathrm{W}, 26$ Sep 2002, UFLA collectors.

Diagnosis. Hypostomus heraldoi is distinguished from all congeners, except $H$. albopunctatus, by having the pectoralfin spine length equal to or smaller than the pelvic-fin spine. From $H$. albopunctatus, it is distinguished by having roundish dark ( $v s$. pale) spots on body and fins, and generally with more premaxillary teeth, 39-59 per ramus (vs. 32-42; see Table 2).

Description. Counts and measurements in Table 1. Body relatively short with rough plates. Cleithral width greater than head depth. Dorsal profile rising convexly at an angle of approximately $30^{\circ}$ from snout tip to dorsal-fin origin, then decreasing linearly to end of caudal peduncle. Head broad and depressed, dorsally covered with dermal ossifications, except for small naked area on snout tip. Anterior profile of 


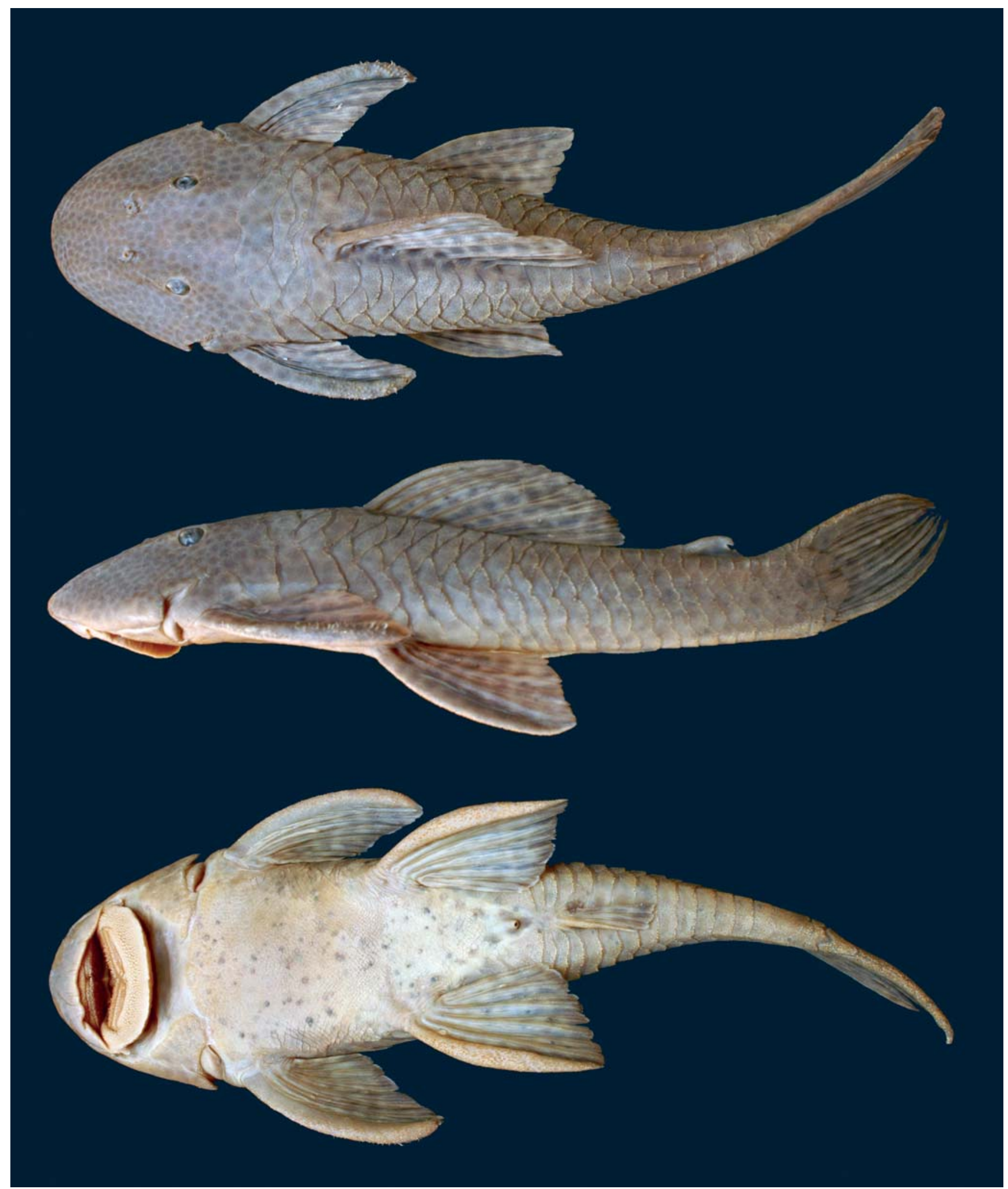

Fig. 5. Hypostomus heraldoi, holotype, Brazil, Goiás State, Município de Caldas Novas, rio Pirapitinga, MZUSP 98771, 217.9 $\mathrm{mm}$ SL. Dorsal, lateral, and ventral views.

snout rounded in dorsal view. Median longitudinal bulge associated with mesethmoid usually conspicuous from snout tip to transverse line between nares. Eye small (12.0 to 13.7\% of HL), dorsolaterally placed. Interorbital space straight or slightly convex in frontal view. A pair of weak ridges on dorsal surface of head, each one beginning lateral to naris, passing through upper margin of orbit and finishing on central portion of pterotic-supracleithrum. Supraoccipital bone with- 
Table 2. Frequency of premaxillary teeth in Hypostomus albopunctatus and $H$. heraldoi.

\begin{tabular}{|c|c|c|c|c|}
\hline \multirow[b]{2}{*}{ Teeth range } & \multicolumn{2}{|c|}{ H. albopunctatus } & \multicolumn{2}{|c|}{ H. heraldoi } \\
\hline & $\mathrm{N}$ & $\%$ & $\mathrm{~N}$ & $\%$ \\
\hline $22-25$ & 1 & 5.0 & & \\
\hline $26-30$ & 6 & 30.0 & & \\
\hline $31-35$ & 8 & 40.0 & & \\
\hline $36-40$ & 4 & 20.0 & 1 & 5.0 \\
\hline $41-45$ & 1 & 5.0 & 2 & 10.0 \\
\hline $46-50$ & & & 5 & 25.0 \\
\hline $51-55$ & & & 6 & 30.0 \\
\hline $56-59$ & & & 6 & 30.0 \\
\hline
\end{tabular}

out median ridge, and with short and rounded posterior process bordered by partially divided predorsal plate.

Lips small and transversely ellipsoid. Lower lip not reaching transverse line between gill openings, its inner surface covered with numerous small papillae. Maxillary barbel very short, largely coalesced with lower lip but with free tip. Mouth moderate. Teeth medium sized, robust, bicuspid, and curved inward distally; inner cusp with elongated crown, about twice length of lateral cusp. Dentary teeth usually not overlapping medially. Dentary ramus forms angle of approximately $140^{\circ}$.

Five rows of slightly spinulose plates on side of body. Predorsal region and all plates in lateral series usually without conspicuous keels. Dorsal series of plates starting at vertical through dorsal-fin origin. Mid-dorsal series interrupted by first plate of dorsal series. Median series bearing lateral line; interrupted by ventrally oriented expansions of plates in mid-dorsal series in region just below dorsal-fin base. Midventral series without keel or with very weak keel restricted to first three plates. Plates in ventral series weakly angled transversely on caudal peduncle; angle more pronounced posteriorly. Caudal peduncle roughly triangular in cross section.

Ventral surface of head mostly covered with minute platelets except beneath lower lip and along outer edge of upper lip. Abdomen covered with minute platelets, even in smaller specimens, except for small naked areas near pectoral and pelvic-fin insertions and surrounding urogenital opening in some specimens. Preanal plate partially exposed.

Dorsal-fin origin situated two lateral plates anterior to vertical through pelvic-fin origin. Dorsal fin small with flexible spine and seven branched rays; two posteriormost rays touching second plate anterior to azygous pre-adipose plate. Adipose-fin spine well developed in most specimens, straight or slightly curved inward. Pectoral fin with slightly inwardcurved spine and six branched rays; posterior margin straight. Pectoral-fin spine covered with poorly-developed odontodes; odontodes more developed distally in larger specimens. Pectoral fin inserted on same horizontal plane as pelvic fin such that pectoral spine, when adpressed, lies on top of and reaches between basal one-fourth to one-third of pelvic-fin spine. Pelvic fin with flexible and slightly inward-curved spine and five branched rays; distal margin straight. Pelvic-fin spine slightly flattened ventrally; when adpressed, tip reaches to distal one-third of anal-fin spine. Anal fin with flexible spine and four branched rays; spine tip reachs to sixth plate poste- rior to its origin. Caudal fin slightly forked, with two outer spines and 14 inner branched rays; ventral lobe longer than dorsal lobe.

Color in alcohol. Background color of dorsal and lateral surfaces of head and trunk brown and covered by darker spots. Spots closely to moderately spaced, and slightly faded in some specimens. Dark spots smaller, more compact and numerous on head, becoming slightly larger, and more dispersed posteriorly. Background color of ventral surfaces of head and body lighter than superior portions. Upper lip uniformly dark except for lighter border. Spots on ventral surface of head and body present but vary in conspicuousness among specimens. Ventral spots roundish and isolated in some specimens; spots merged into vermiculations in others. Caudal peduncle region with very faded dark spots ventrally.

Dorsal, pectoral, pelvic and caudal fins with roundish dark spots on spines and rays; spots weakly aligned to form five to seven transverse bands. Dorsal fin sometimes with dark spots merging to form irregular bands on interradial membranes paralleling rays. Adipose fin spotless or with irregular dark spots. Anal fin with dark spots generally merged into two or three transverse bands.

Distribution and habitat. Hypostomus heraldoi is known from the rio Corumbá and rio Grande drainages, upper rio Paraná basin (Fig. 4). The Corumbá Reservoir and its tributary rio Pirapitinga are the main sites where $H$. heraldo $i$ was collected. The water was turbid, substrates rocky with sand, and riparian vegetation variable and remnant. This species was not found associated with woody debris, and, like $H$. denticulatus, occurs syntopically with $H$. ancistroides, $H$. iheringii, $H$. margaritifer, $H$. regani and Hypostomus sp.

Etymology. Hypostomus heraldoi is named in honor of Heraldo Antônio Britski, MZUSP (Museu de Zoologia da Universidade de São Paulo), for his extensive contributions to our knowledge of neotropical fish diversity.

\section{Discussion}

Hypostomus denticulatus is morphologically very similar to H. iheringii (Regan), H. latirostris (Regan), H. ternetzi (Boulenger) and $H$. multidens Jerep, Shibatta \& Zawadzki, sharing with these species characters such as a wide jaw, deep caudal peduncle, conspicuous keel on supraoccipital process and predorsal plates, and abdominal plates restricted to anterior portion of the abdomen with extensive naked areas surrounding pelvic-fin insertion. Hypostomus ternetzi and H. cf. iheringii (= Hypostomus sp. 2 sensu Zawadzki et al., 2005) share a unique allozyme pattern among 11 species of Hypostomus examined from the upper Paraná basin. This pattern corroborates their similarities in external morphology, and both species were placed in the $H$. ternetzi group by Zawadzki et al. (2005). Hypostomus multidens and H. denticulatus also seem to fit this group. Hypostomus multidens exhibits some 
morphological traits of the $H$. ternetzi group, but differs by having light (vs. dark) spots on body and fins, and symmetrical (vs. asymmetrical) bicuspid teeth. Hypostomus denticulatus also has teeth with two symmetrical cusps, but has large dark spots on body and fins as do the other members of the H. ternetzi group. Hypostomus mutucae Knaack has broad lower jaws similar to $H$. denticulatus, but differs by lacking a medium crest on predorsal plates, and by having asymmetrical cusps and putatively smaller adult size (e.g., holotype is $67.1 \mathrm{~mm} \mathrm{SL}$ and a specimen from MZUSP 27694 is $75.3 \mathrm{~mm} \mathrm{SL})$.

Hypostomus heraldoi is morphologically very similar to H. albopunctatus from the rio Piracicaba basin despite having black spots instead of pale ones. Hypostomus albopunctatus was up to now the only species of Hypostomus having the pectoral-fin spine equal to or shorter than the pelvic-fin spine. Zawadzki (2001) found an allele at locus PgmA diagnosing $H$. heraldoi (= Hypostomus sp. 1) from six other species of Hypostomus in the rio Corumbá basin. Later, Zawadzki et al. (2005) found this same allele diagnostic of $H$. albopunctatus among ten Hypostomus species from the Itaipu Reservoir. Thus, genetic data and external morphology suggest that these two species are related, yet clearly distinguished by color pattern and to a lesser degree by the number of premaxillary teeth (i.e., 39-59 per ramus in $H$. heraldoi vs. 32-42 in H. albopunctatus).

Each of the two new species described herein show a color pattern opposite to that of its morphologically most similar species. This suggests that some genetic trigger may influence speciation events in some Hypostomus by inversion of the color pattern. The precise phylogenetic placement of both new species is beyond the scope of this paper. Further morphological and molecular studies will be necessary to confirm sister relationships between species with inverted color patterns.

The Corumbá dam has dramatically changed the lotic environment of the rio Corumbá to a lentic one, and the extent to which these modifications affect fish populations is still unknown. Although the lower stretches of the rio Paraná have been extensively surveyed, $H$. denticulatus and $H$. heraldoi have never been collected outside the rio Grande and rio Paranaíba basins, and are probably endemic to these watersheds. The rio Paranaíba supports a number of endemic fishes and its isolation from the remaining Paraná basin is attributed to a series of rapids and canyons downstream its mouth that apparently represent barriers to free dispersal (Pavanelli \& Britski, 1999).

Comparative material. All from Brazil: H. albopunctatus: NUP 5401, 10, 33.6-177.5 mm SL, rio Piracicaba basin, rio Passa Cinco; Hypostomus ancistroides: NUP 472, 3, 85.5-106.4 mm SL, rio Paranaíba basin, rio Corumbá; H. iheringii: NUP 4040, 1, $131.3 \mathrm{~mm}$ $\mathrm{SL}$, rio Paranaíba basin, rio Corumbá; H. latirostris: $\mathrm{BMNH}$ 1892.4.20.26-27, 2 (137.2-159.3 mm SL), syntypes of Hypostomus latirostris Regan, 1904, rio Paraguay basin, rio Jangada; $H$. margaritifer: NUP 4041, 2, 131.3-161.1 mm SL, rio Paranaíba basin, rio Corumbá; H. multidens: NUP 5340, 1, 157.0 mm SL, upper rio Paraná basin, rio Paranapanema; H. mutucae: MZUSP 27694, 2, 75.4-79.8 mm SL, rio Cuiabá basin, rio Mutuca; H. regani: NUP 4301, 1, $161.3 \mathrm{~mm}$ SL, rio Paranaíba basin, rio Corumbá; $H$. strigaticeps: NUP 4055, 2, 117.1-118.5 mm SL, rio Paranaíba basin, rio Sapé; H. ternetzi: NUP 1765, 1, 204.0 mm SL, upper rio Paraná basin, rio Paraná at Itaipu Reservoir.

\section{Acknowledgements}

We thank João Latini, Samuel Veríssimo, and Wladimir Domingues (UEM/Nupélia) for collecting samples in Corumbá Reservoir; Barbara Brown (AMNH), David Catania (CAS), Helmut Wellendorf(NMW), Karsten Hartel (MCZ), Margarete Lucena (MCP), Mark Sabaj Pérez (ANSP), Mary Anne Rogers (FMNH), Osvaldo Oyakawa (MZUSP), Patrick Campbell (BMNH), Patrice Pruvost (MNHN), Paulo Buckup (MNRJ), Ronald Vonk (ZMA), and Sonia Fisch-Muller (MHNG) for loaning comparative material and hosting museum visits, and Jaime Pereira for help with tooth drawings. Nupélia and FURNAS Centrais Elétricas provided logistical support. All authors participate in the Planetary Biodiversity Inventory: All Catfish Species (Siluriformes) - Phase I of an Inventory of the Otophysi, a five year grant through the US National Science Foundation to describe all species of catfishes (DEB0315963), which provided grants to CHZ. CSP partially supported by $\mathrm{CNPq}$ (Conselho Nacional de Desenvolvimento Científico e Tecnológico; proc. 311975/2006-2).

\section{Literature Cited}

Armbruster, J. W. 2004. Phylogenetic relationships of the suckermouth armored catfishes (Loricariidae) with emphasis on the Hypostominae and the Ancistrinae. Zoological Journal of the Linnean Society, 141: 1-80.

Armbruster, J. W., L. A. Tansey \& N. K. Lujan. 2007. Hypostomus rhantos (Siluriformes: Loricariidae), a new species from southern Venezuela. Zootaxa, 1553: 59-68.

Boeseman, M. 1968. The genus Hypostomus Lacépède, 1803, and its Surinam representatives (Siluriformes, Loricariidae). Zoologische Verhandelingen, 99: 1-89.

Britski, H. A. \& F. Langeani. 1988. Pimelodus paranaensis, sp. n., um novo Pimelodidae (Pisces, Siluriformes) do alto Paraná, Brasil. Revista Brasileira de Zoologia, 5: 409-417.

Ferraris Jr., C. J. 2007. Checklist of catfishes, recent and fossil (Osteichthyes: Siluriformes), and catalogue of siluriform primary types. Zootaxa, 1418: 1-628.

Jerep, F. C., O. A. Shibatta \& C. H. Zawadzki. 2007. A new species of Hypostomus Lacépède, 1803 (Siluriformes, Loricariidae) from the upper Rio Paraná basin, Southern Brazil. Neotropical Ichthyology, 5: 435-442.

Oyakawa, O. T., A. Akama \& A. M. Zanata. 2005. Review of the genus Hypostomus Lacépède, 1803 from Rio Ribeira de Iguape basin, with description of a new species (Pisces, Siluriformes, Loricariidae). Zootaxa, 921: 1-27.

Pavanelli, C. S. \& H. A. Britski. 1999. Description of a new species of Steindachnerina (Teleostei: Characiformes: Curimatidae) from the upper Rio Paraná basin, Brazil. Ichthyological Exploration of Freshwaters, 10: 211-216.

Pavanelli, C. S., W. J. Graça, C. H. Zawadzki, H. A. Britski, A. P. 
Vidotti, G. S. Avelino \& S. Veríssimo. 2007. Fishes from the Corumbá Reservoir, Paranaíba River drainage, upper Paraná River basin, State of Goiás, Brazil. Check List, 3: 58-64.

Schaefer, S. A. 1997. The Neotropical cascudinhos: systematics and biogeography of the Otocinclus catfishes (Siluriformes: Loricariidae). Proceedings of the Academy of Natural Sciences of Philadelphia, 148: 1-120.

Vari, R. P. 1988. The Curimatidae, a lowland Neotropical fish family (Pisces: Characiformes): distribution, endemism, and phylogenetic biogeography. Pp. 343-377. In: Heyer, W. R. \& P. E. Vanzolini (Eds.). Proceedings of the Workshop on Neotropical Distribution Patterns. Rio de Janeiro, Academia Brasileira de Ciências.

Weber, C. 1985. Hypostomus dlouhyi, nouvelle espèce de poissonchat cuirassé du Paraguay (Pisces, Siluriformes, Loricariidae). Revue suisse de Zoologie, 92: 955-968.

Weber, C. 2003. Subfamily Hypostominae. Pp. 351-372 In: R.E. Reis, S. O. Kullander \& C. J. Ferraris Jr (Eds.). Check List of the Freshwater Fishes of South and Central America. Porto Alegre, Edipucrs, 729 p.

Zawadzki, C. H. 2001. Sistemática e variação aloenzimática da família Loricariidae (Teleostei: Siluriformes) dos reservatórios de Corumbá e Itaipu na bacia do alto Rio Paraná, Brasil. Unpublished Ph.D. Thesis, Universidade Estadual de Maringá, Maringá.

Zawadzki, C. H., E. Renesto, R. E. Reis, M. O. Moura \& R. P. Mateus. 2005. Allozyme relationships in hypostomines (Teleostei: Loricariidae) from the Itaipu Reservoir, Upper Rio Paraná basin, Brazil. Genetica, 123: 271-283.

Accepted August, 2008

Published September 30, 2008 